\title{
Yield and nutrient uptake in niger (Guizotia abyssinica) as influenced by different levels of nitrogen, phosphorus, potassium and sulphur
}

\author{
P. Bora*, P. C. Bora, K. Kurmi and S. Kalita \\ Department of Agronomy, Assam Agricultural University, Jorhat (Assam) India \\ (Email: borapriyanka91@gmail.com)
}

\begin{abstract}
A field experiment was conducted during the Rabi seasons of 2016-17 and 2017-18 at Instructional-Cum-Research (ICR) Farm, Assam Agricultural University, Jorhat to study the effect of different levels of primary major nutrients (nitrogen, phosphorus and potassium) as well as secondary nutrient (sulphur) on the uptake of the same by niger and yield of the crop. The experiment was laid out in Factorial Randomized Block Design and replicated thrice. The treatments consisted of three NPK levels viz., $\mathrm{F}_{1}\left(20-10-10 \mathrm{~kg} \mathrm{~N}-\mathrm{P}_{2} \mathrm{O}_{5}-\mathrm{K}_{2} \mathrm{O} \mathrm{ha}^{-1}\right), \mathrm{F}_{2}\left(25-12.5-12.5 \mathrm{~kg} \mathrm{~N}-\mathrm{P}_{2} \mathrm{O}_{5}-\mathrm{K}_{2} \mathrm{O} \mathrm{ha}^{-1}\right), \mathrm{F}_{3}\left(30-15-15 \mathrm{~kg} \mathrm{~N}-\mathrm{P}_{2} \mathrm{O}_{5}-\mathrm{K}_{2} \mathrm{O}^{-1}\right)$ and three sulphur levels viz., $\mathrm{S}_{1}$ (no sulphur), $\mathrm{S}_{2}\left(10 \mathrm{~kg} \mathrm{Sha}^{-1}\right), \mathrm{S}_{3}\left(20 \mathrm{~kg} \mathrm{~S} \mathrm{ha}^{-1}\right)$. Application of $\mathrm{F}_{3}\left(30-15-15 \mathrm{~kg} \mathrm{~N}-\mathrm{P}_{2} \mathrm{O}_{5}-\mathrm{K}_{2} \mathrm{O} \mathrm{ha}^{-1}\right)$ and $\mathrm{S}_{3}(20 \mathrm{~kg}$ sulphur $\mathrm{ha}^{-1}$ ) significantly increased the nitrogen, phosphorus, potassium and sulphur uptake by seed and stover as well as their total uptake by niger as compared to other treatments during both the years of study. Seed yield and protein content (\%) of seed of niger were also increased significantly by application of $\mathrm{F}_{3}\left(30-15-15 \mathrm{~kg} \mathrm{~N}-\mathrm{P}_{2} \mathrm{O}_{5}-\mathrm{K}_{2} \mathrm{O} \mathrm{ha}^{-1}\right)$ and $\mathrm{S}_{3}(20 \mathrm{~kg}$ sulphur ha-1) as compared to other treatments during both the years. Interaction effects of NPK (F) and sulphur (S) were found to be significant in respect of seed yield, nitrogen, phosphorus, potassium and sulphur uptake by seed as well as total nitrogen uptake by niger during both the years and phosphorus uptake by niger was found to be significant only in the first year of study.
\end{abstract}

Key Words : Niger, Nitrogen, Phosphorus, Potassium, Sulphur

View Point Article : Bora, P., Bora, P.C., Kurmi, K. and Kalita, S. (2021). Yield and nutrient uptake in niger (Guizotia abyssinica) as influenced by different levels of nitrogen, phosphorus, potassium and sulphur. Internat. J. agric. Sci., 17 (2) : 502-508, DOI:10.15740/HAS/ IJAS/17.2/502-508. Copyright@2021: Hind Agri-Horticultural Society.

Article History : Received : 01.03.2021; Revised : 04.03.2021; Accepted : 18.03.2021

\footnotetext{
* Author for correspondence :
} 